\section{CHEMISTS IN CONFERENCE.}

THE Society of Chemical Industry held its annual meeting in London on July $15^{-18}$, and, in order to emphasise the fact that its outlook is industrial rather than academic, the conferences took place in the City, and not, as hitherto, in South Kensington. The opening meeting was held at the Mansion House, and the society was welcomed by the Lord Mayor; other conferences were held at the Salters' Hall, Goldsmiths' Hall, and Clothworkers' Hall, and the foreign delegates were privileged to lunch in the picturesque and old-world hall of the Girdlers' Company.

It has already been announced in these columns that an Inter-Allied Chemical Council has been formed for the promotion of co-operation between the chemists of Belgium, France, Great Britain, Italy, and the United States. During the last year or so there has also grown into existence an International Research Council, which has met in Rome and Paris, and is this week holding an important conference in Brussels. This council contemplates the organisation of research and publication in all branches of science and in all countries, except Germany and Austria, and there was a good deal of discussion among the British and Allied chemists at their conferences last week as to how the Inter-Allied Council could fit into the scheme of organisation contemplated by the International Research Council. It was at length decided to announce that the Inter-Allied Chemical Council was of opinion that this body should be the chemical section of the International Research Council, and should do all the work of organisation and publication which was required in connection with chemistry, both pure and applied. A deputation was sent to Brussels to express this view and to co-operate with the other savants there assembled. Amongst the delegates to Brussels we may mention Prof. Chavanne, Dr. Lucion, and M. Timmermans, representing Belgium; Profs. Moureu and Béhal, representing France; Sir William Pope and Dr. Ruttan (of Canada), representing the British Empire; and Lt.-Col. Bartow, Dr. Parsons, and Dr. Washburn, representing the United States. It is understood that Canada and Poland have expressed a wish to be represented on the Inter-Allied Chemical Council, and are now admitted as such, and that the other Allies who have signed the Treaty of Peace will be asked to become constituent bodies.

Among the papers read at the Mansion House on July is was a very eloquent and interesting appreciation of the late Sir William Ramsay by Prof. C. Moureu, the president of the Inter-Allied Council. Prof. Moureu described the researches of the late Lord Rayleigh on the density of nitrogen, and gave an account of the excitement produced at the British Association at Oxford in 1894 when Lord Rayleigh and Sir William Ramsay announced their discovery of argon. He mentioned as characteristic of Sir William Ramsay the speed with which he followed up a hint given in a letter from Sir Henry Miers as to a gas contained in cleveite and detected by Hillebrand. This led to the discovery of helium, which was spectroscopically detected in the sun so long ago as I 868.

Prof. Moureu gave some account of his own original work on the occurrence of helium in fire-damp and in the gases given off by underground springs, and sketched the history of the discovery of neon, krypton, and xenon. Only those who have paid attention to the recent publications are aware that helium occurs to the extent of 6 per cent. in the gases given off by the spring at Maizières, in the Côte d'Or, and to the extent of ro per cent. in the gas of the spring at
Santenay, also in the Côte d'Or. Moreover, krypton, argon, xenon, and neon are usually found in the subterranean gases, and the relative proportions of these four gases are fairly constant. The explanation is suggested that these gases, being chemically inactive, have remained in a constant proportion since the days when our globe was a nebular mass without form and void. It was Sir William Ramsay himself who predicted the use of helium for filling balloons-a prediction which has been recently verified by the work done in the United States under the superintendence of Dr. Cottrell.

An important conference on the production and consumption of sugar within the British Empire was held at the Clothworkers' Hall, the Earl of Denbigh being in the chair. A number of experts took part in the discussion, and a voluminous report is now being prepared for publication.

A group of papers on power plant in chemical works occupied a whole day; these included a paper on waste heat boilers by Capt. C. J. Goodwin and a paper on surface combustion boilers by Prof. W. A. Bone and Mr. P. Kirke. Several speakers directed attention to possible economies in the use of fuel-a matter which is now of the utmost importance to the whole nation.

The conference on dyestuffs was largely attended; and a paper by Dr. Herbert Levinstein on the intimate connection between the German dye manufactures and the supply of explosives and poison gases should make our politicians think furiously. Germany, notwithstanding the Treaty of Peace, is left in the position that she can easily, at a few hours' notice, commence the manufacture of explosives and poison gas on a very large scale. In this country we have at the moment no manufacture which can proceed during peace and at once be switched on to varlike purposes. Mr. E. V. Evans, in his paper on the manufacture of intermediate products in the dyestuff industry, showed how desirable it is to conduct the manufacture of these in a few works on a large scale rather than, as now, the manufacture on a small scale in many works.

There were good papers on other topics dealing, perhaps, with rather technical matters, and a number of papers on chrome tanning and on recent developments in the fermentation industries, including one by Sir Frederick Nathan on the manufacture of acetone.

Industrial chemistry is becoming too large a subject for any individual to master, and the tendency to specialise is manifested, not only in the grouping of a number of cognate papers into one conference, but also in the activities of the recently formed chemical engineering group of the society. On the whole, the papers were of considerable importance, and show that, though the chemists may be tired by their war-work, they are not exhausted.

\section{PHYSIOLOGY AND METAPHYSICS.}

A JOINT session of the Aristotelian Society, the British Psychological Society, and the Mind Association has been held annually, though more or less informally, since Igo8. This year an attractive and more extended programme was provided on July II-I4, and hospitality was offered by Bedford College, the most delightfully situated and admirably appointed of the University of London colleges. The result was a very large increase in the membership and a sustained interest in the session. Members were furnished in advance with the whole of the written communications constituting the Proceedings. This 
had the advantage that at every meeting the papers were taken as read, and the leaders of the discussions could concentrate at once on the important points in theory or criticism of theory which they had set forth.

The subject of discussion at the first meeting was "Propositions: What They Are and How They Mean." The paper was by Mr. Bertrand Russell. It was the outcome of a philosophical research into the tenability of the behaviourist theory in psychology. The neutral monism which forms the basis of this theory had proved very attractive to Mr. Russell, and he put forward as his own view that it is true in so far as that the psychical and the physical are not distinguishable by the stuff of which they are made; but by the order of the causal laws to which they are amenable. He parted from behaviourism, however, on the question of "images." So far as he had been able to go at present, he was convinced that there are images, and he could see no way of interpreting them in physical terms. An interesting discussion followed, led by Dr. G. E. Moore, who presided.

The second meeting attracted the largest audience of the session. The subject was a symposium on "Instinct and the Unconscious," to which Dr. W. H. R. Rivers, Dr. C. S. Myers, Dr. C. G. Jung (of Zurich), Prof. Graham Wallas; Dr. J. Drever, and Dr. W. McDougall contributed. Sir Leslie Mackenzie presided. The interest of this discussion centred round the neurological and psychological discoveries in regard to war-neuroses. Dr. Jung received a warm welcome, and surprised everyone by the ease and fluency with which he expounded his theory in English. The theory created a lively impression. At a subsequent meeting its more philosophical aspect, particularly its relation to Bergson's doctrine of a vital impulse, was the subject of a discussion opened by Mr. J. W. Scott.

The third meeting was a symposium on "Space, Time, and Material: Are They, and if so in what Sense, the Ultimate Data of Science?" Sir Joseph Larmor presided. Sir Oliver Lodge, who had contributed one of the papers, was unavoidably absent, and a reply to a criticism of his thesis was read. The other contributors were Prof. A. N. Whitehead, Prof. J. W. Nicholson, Dr. Henry Head, Mrs. Adrian Stephen, and Prof. Wildon Carr. Two problems emerged in the discussion: the physical problem of continuity and the physiological problem of the nature of the mechanisms and neurological contrivances which condition conscious experience. Prof. Whitehead contended that the first chapter in science, i.e. in the systematisation of Nature, must deal with an event. Process is the fundamental fact which requires explanation; there is no element in experience prior to and simpler than an event.

The fourth meeting was devoted to the metaphysical problem of the relation of the finite to the infinite, or, in the terms of the symposium, "Can Finite Minds be Included in the Mind of God?" Lord Haldane presided. The papers were by the Dean of Carlisle, Dr J. H. Muirhead, Dr. F. C. S. Schiller, and the Bishop of Down.

The fifth and final meeting was a symposium on "Is there "Knowledge by Acquaintance'?" The papers were by Prof. G. Dawes Hicks, Dr. G. E. Moore, Dr. Beatrice Edgell, and Mr. C. D. Broad. Prof. W. R. Sorley was in the chair.

The dominant note in the discussions was, to most of those taking part, the physiological problem. Dr. Head's description of his researches, based on the treatment of war injuries, into the function of the cerebral cortex, and his theory of the survival of older responses beneath the superposed control of the higher centres, though freely criticised, was felt to have important consequences both for psychological and epistemological theory. Also. it left the impression of a new and unsuspected approach to one another of science and philosophy.

The meeting in 1920 is to take place at Oxford, and it is intended to invite the participation of the Société Française de Philosophie.

\section{A LEAGUE OF UNIVERSITIES.}

A CONFERENCE of Universities was held at the Imperial Institute on July is. It was convened in order that representatives of British universities, including such members of the universities of the King's Dominions overseas as are still in England in connection with the war, might take counsel with their colleagues from the U.S.A. Notwithstanding the difficulties created by Peace Day, especially in regard to finding hotel accommodation, the conference was well attended. The subject for discussion was the contemplated extension of the activities of the Universities Bureau. Representatives were invited to give expression to their views regarding the ways in which the Bureau might be of greater service to the universities.

The chairman, Sir Donald MacAlister, was able to announce that, the Treasury having, on the advice of the President of the Board of Education, promised to the Bureau a non-recurrent grant of $5000 l$., provided the universities made adequate provision for its maintenance, almost all the universities of the United Kingdom had already adopted a proposal made at the last mecting of the conference for each to contribute a sum of rool. per annum to the Bureau funds, and two of the university colleges had promised $5 \mathrm{ol}$. each. The Treasury grant is intended to enable the Bureau Committee to acquire and furnish premises suitable for the accommodation of the staff and for the reception of visiting professors and immigrant students from the Dominions and foreign countries. Probably in a short time it will be possible to announce the address of the new headquarters.

When the delegates who attended the congress of rgr2 decided that it was desirable that a "clearinghouse" for universities should be established, they were thinking of it chiefly as an agent for promoting co-operation amongst the universities of the Empire, although its international relations were not absent from their minds. No one then could have foreseen that during the autumn of 1914 and the year which followed, the secretary of the Bureau would be in correspondence with all the universities and colleges of the United States and other neutral countries, or sending them parcels of State papers, books, and pamphlets on the causes of a great war, the responsibility for it, and the moral issues which it raised. Nor could anyone have foreseen that, as an outcome of the war, there would be an urgent demand for co-operation amongst the universities of the Allied and neutral countries, and especially for the interchange of teachers and graduate students, on a scale which will appreciably affect our knowledge of one another's ways of thought and trend of sentiment.

All who look to the League of Nations as the only guarantee of peace recognise that one of its strongest supports would be a League of Universities. In illustration of what may be done to promote such a league, the nine representatives of the universities of the United Kingdom and Capt. Holme, who represented the universities of Australasia, gave an account of their experiences and of the impressions which they received during their recent visit to France as guests of the French Republic, and Dr. Fish, on behalf of Dr. Duggan, the director, who was detained in France, described the aims of the new American Institute of International Education. NO. 2595 , VOL. IO3] 